\title{
THERMODYN AMIC PROPERTIES OF BUTYL METHACRYLATE SOLUTIONS IN ORGANIC SOLVENTS
}

\author{
Valentyn Serheyev1, * , Tran Van Thanh ${ }^{1}$
}

https://doi.org/10.23939/chcht12.01.007

\begin{abstract}
The saturated vapor pressure of butyl methacrylate solutions in acetonitrile, benzene, hexane and 1,2-diclorethane was measured by static tensimetric method in the temperature range of $291-351 \mathrm{~K}$. The composition of the equilibrium phases and the activity factors were received from the experimental measurements of the temperature-dependent saturated vapor pressure. We then used the temperature and concentration dependent activity factors to calculate the thermodynamic functions of mixing of the solutions.
\end{abstract}

Keywords: butyl methacrylate, saturated vapor pressure, activity coefficients, vapor-liquid equilibrium, excess thermodynamic functions.

\section{Introduction}

Alkylacrylic acids and their esters are important raw materials for the synthesis of polymers with a wide range of properties. The thermodynamic properties of the individual neat components have been extensively studied [1]. There are also a number of studies of the liquid-vapor equilibrium of the solutions of acrylic acid and their ethers. Most works [2-5] are focused on the liquid-vapor equilibrium for solutions of acrylic and methacrylic acids and their ethers under isobaric conditions and the pressure of $101.3 \mathrm{kPa}$. Based on the experimental values, parameters of the Local Composition Models [6-7] were evaluated. These equations may be used to calculate the parameters of liquid-vapor equilibrium at different pressures. Such studies of liquid-vapor equilibrium are useful, as they would provide the necessary information on the behavior of the individual components in these complex systems. In this work the excess thermodynamic functions of mixing of solutions were calculated based on the experimental data of the temperature dependence of vapor pressure of butyl methacrylate solutions in acetonitrile, benzene, hexane and 1,2-diclorethane. The

\footnotetext{
${ }^{1}$ Lviv Polytechnic National University

12, Bandery St., 79013 Lviv, Ukraine

vsergeev@.polynet.lviv.ua

(C) Serheyev V., Thanh T., 2018
}

solvents were chosen according to the following criteria: a solvent must be widely used, to have a high vapor pressure at the experimental temperatures and a boiling point of not lower than $340 \mathrm{~K}$. A particular utility of our data is that they can be used to directly calculate the composition of the equilibrium phases for the investigated systems within the studied temperature and pressure ranges.

This article is a continuation of our publications about properties of solutions of acrylic-based acids and their esters [8-13]. In this work, to estimate the thermodynamic functions of mixing based on the vapor-liquid equilibrium, we adopted the commonly used methodology developed by Belousov and Morachevsky [14].

\section{Experimental}

The raw materials used for the investigations were of the commercial grade and were supplied by MERCK (Germany). The chemicals received were further purified through repeated evaporation and additionally by recrystallization with benzene. The chemicals were then selected based on their unique boiling temperature as well as the refractive index and density. Purity of the substances was determined by chromatograph LHM-8D with a detector on heat conductivity. The content of impurities in the purified substances was not more than $0.2 \mathrm{wt} \%$.

We measured the saturated vapor pressure of the solutions with constant compositions at various temperatures on the basis of static methodology approach [10].

Experimental device for measuring vapor pressure was hermetically sealed container of $20 \mathrm{~cm}^{3}$ capacity with integrated pressure sensor Sensor Technics STE8N01 with a silicon membrane.

Experiments were conducted using approximately $10 \mathrm{ml}$ of solution. To minimize evaporation the system was cooled to $250 \mathrm{~K}$ and vacuumized. Then, it was heated to $360 \mathrm{~K}$ to decrease the amount of dissolved gas, again cooled and vaccumized. This procedure was repeated several times (typically, five times), to ensure the residual pressure in the system would not be greater than $10 \mathrm{~Pa}$.

The experimental setup was placed in the water thermostat. Varying the temperature in the thermostat 
(resolution accuracy of $0.1 \mathrm{~K}$ ) from 295 to $355 \mathrm{~K}$, we determined the saturated vapor pressure values. Temperature range is conditioned by the characteristics of the water thermostat.

The temperature was changed discretely in the direction of its increase. We considered that the equilibrium was reached when the vapor pressure did not change for $15 \mathrm{~min}$. Since the volumes of liquid and gas phases were the same, the change in the liquid phase composition due to evaporation of the most volatile component did not exceed $0.2 \mathrm{~mol} \%$. Standard measurement error for pressure was $\pm 65 \mathrm{~Pa}$, temperature $\pm 0.1 \mathrm{~K}$.

To validate the experimental procedure, as well as the correctness of our approach, we conducted a series of experiments with well-known substances, such as heptane and hexane. The obtained results were in agreement with reported literature data [15].

\section{Results and Discussion}

To study the experimental systems we prepared several solutions with the concentration range from 10 to
$90 \mathrm{~mol} \%$. The concentration represents the most volatile component, which in all cases was a solvent. Notably, to prevent the undesired polymerization of butyl methacrylate we added an inhibitor - hydrochinon $(\leq 0.2 \mathrm{wt} \%)$. Such concentration of the inhibitor did not influence the measurements. The concentration of the solutions was measured using chromatography, after the system was cooled to $298 \mathrm{~K}$.

We used Antoine equation (1) to fit the experimental data of the temperature dependent of saturated vapor pressure for investigation solutions, as well as the literature data of the individual components $[1,15]$ :

$$
\lg p(P a)=A-\frac{B}{(T(K)+C)}
$$

Coefficients of the equation were calculated by the least squares method. The fitting coefficients, the dispersion of experimental values, and temperature rangesevaluated in a given temperature range are listed in Table 1.

Small deviation of experimental dispersion values from the values calculated by Eq. (1) shows that this equation adequately describes the temperature dependence of the vapor pressure for investigated systems.

Table 1

Fitting coefficients of Antoine equation

\begin{tabular}{|c|c|c|c|c|c|}
\hline$x, \mathrm{~mol} \%$ & $\mathrm{~A}$ & B & $\mathrm{C}$ & Temperature range, $\mathrm{K}$ & $\mathrm{Sn}, \mathrm{kPa}$ \\
\hline \multicolumn{6}{|c|}{ Acetonitrile - Butyl methacrylate } \\
\hline 0.0 & 9.31972 & 1609.88 & -60.83 & $273-435$ & [1] \\
\hline 12.4 & 7.75105 & 884.76 & -87.86 & $295-350$ & 0.05 \\
\hline 29.0 & 8.01131 & 888.13 & -87.83 & $295-350$ & 0.04 \\
\hline 48.5 & 8.87658 & 1247.54 & -46.80 & $295-350$ & 0.09 \\
\hline 69.1 & 9.51999 & 1562.57 & -15.71 & $295-350$ & 0.10 \\
\hline 88.7 & 8.97496 & 1201.18 & -54.65 & $295-350$ & 0.08 \\
\hline 100.0 & 9.28443 & 1355.37 & -37.85 & $288-362$ & [15] \\
\hline \multicolumn{6}{|c|}{ Benzene-Butyl methacrylate } \\
\hline 0.0 & 9.31972 & 1609.88 & -60.83 & $273-435$ & [1] \\
\hline 9.6 & 6.75186 & 529.34 & -149.85 & 294-351 & 0.07 \\
\hline 29.3 & 8.00513 & 946.22 & -83.51 & $293-350$ & 0.09 \\
\hline 48.3 & 8.28711 & 976.69 & -80.85 & $291-350$ & 0.13 \\
\hline 69.8 & 8.53632 & 1039.78 & -71.21 & $293-351$ & 0.02 \\
\hline 88.7 & 8.87779 & 1156.31 & -58.11 & $294-351$ & 0.06 \\
\hline 100.0 & 9.02384 & 1203.84 & -53.23 & $287-354$ & [15] \\
\hline \multicolumn{6}{|c|}{ Hexane - Butyl methacrylate } \\
\hline 0.0 & 9.31972 & 1609.88 & -60.83 & $273-435$ & [1] \\
\hline 11.2 & 8.36527 & 1271.54 & -35.91 & $297-347$ & 0.05 \\
\hline 42.3 & 7.85984 & 782.49 & -94.48 & $305-348$ & 0.06 \\
\hline 62.2 & 8.23382 & 883.19 & -81.80 & 294-349 & 0.07 \\
\hline 86.5 & 8.53112 & 956.99 & -73.88 & $296-343$ & 0.13 \\
\hline 100 & 9.00836 & 1171.53 & -48.78 & $286-342$ & [15] \\
\hline \multicolumn{6}{|c|}{ 1,2-Diclorethane - Butyl methacrylate } \\
\hline 0.0 & 9.31972 & 1609.88 & -60.83 & $273-435$ & [1] \\
\hline 13.5 & 7.22655 & 692.25 & -125.72 & $293-350$ & 0.05 \\
\hline 29.2 & 8.23741 & 1035.92 & -79.37 & 293-350 & 0.04 \\
\hline 49.8 & 8.78908 & 1245.35 & -52.28 & $293-350$ & 0.05 \\
\hline 72.1 & 8.78221 & 1154.32 & -62.45 & $293-350$ & 0.06 \\
\hline 92.1 & 9.59484 & 1558.40 & -19.85 & $293-350$ & 0.11 \\
\hline 100.0 & 9.59088 & 1521.79 & -24.67 & $242-372$ & [15] \\
\hline
\end{tabular}


Equilibrium composition, pressure and the activity factors of investigation systems

Table 2

\begin{tabular}{|c|c|c|c|c|c|c|c|c|c|}
\hline$x, \mathrm{~mol} \%$ & $y, \mathrm{~mol} \mathrm{\%}$ & $P, \mathrm{kPa}$ & $\gamma_{1}$ & $\gamma_{2}$ & $x, \mathrm{~mol} \%$ & $y, \mathrm{~mol} \%$ & $P, \mathrm{kPa}$ & $\gamma_{1}$ & $\gamma_{2}$ \\
\hline \multicolumn{10}{|c|}{ Acetonitrile - Butyl methacrylate } \\
\hline \multicolumn{5}{|c|}{$300 \mathrm{~K}$} & \multicolumn{5}{|c|}{$340 \mathrm{~K}$} \\
\hline 0.0 & 0.00 & 0.39 & - & 1.0000 & 0.0 & 0.00 & 3.57 & - & 1.0000 \\
\hline 10.0 & 88.65 & 3.20 & 2.1853 & 1.0000 & 10.0 & 78.69 & 15.08 & 1.8877 & 1.0025 \\
\hline 30.0 & 95.62 & 6.87 & 1.6873 & 1.0677 & 30.0 & 91.65 & 31.57 & 1.5324 & 1.0570 \\
\hline 50.0 & 97.23 & 9.03 & 1.3521 & 1.2392 & 50.0 & 95.00 & 42.45 & 1.2819 & 1.1919 \\
\hline 70.0 & 98.18 & 10.59 & 1.1443 & 1.5948 & 70.0 & 96.91 & 50.79 & 1.1177 & 1.4673 \\
\hline 90.0 & 99.18 & 12.14 & 1.0302 & 2.4795 & 90.0 & 98.71 & 58.71 & 1.0234 & 2.1240 \\
\hline 100.0 & 100.00 & 13.00 & 1.0000 & - & 100.0 & 100.00 & 62.88 & 1.0000 & - \\
\hline \multicolumn{10}{|c|}{ Benzene - Butyl methacrylate } \\
\hline \multicolumn{5}{|c|}{$300 \mathrm{~K}$} & \multicolumn{5}{|c|}{$340 \mathrm{~K}$} \\
\hline 0.0 & 0.00 & 0.39 & - & 1.0000 & 0.0 & 0.00 & 3.57 & - & 1.0000 \\
\hline 10.0 & 81.03 & 1.77 & 1.0053 & 0.9994 & 10.0 & 65.76 & 9.43 & 0.9263 & 0.9983 \\
\hline 30.0 & 93.97 & 4.37 & 0.9765 & 1.0085 & 30.0 & 88.26 & 21.33 & 0.9361 & 0.9950 \\
\hline 50.0 & 97.32 & 7.02 & 0.9769 & 1.0083 & 50.0 & 94.79 & 33.80 & 0.9561 & 0.9803 \\
\hline 70.0 & 98.88 & 9.84 & 0.9942 & 0.9803 & 70.0 & 97.83 & 46.93 & 0.9785 & 0.9457 \\
\hline 90.0 & 99.72 & 12.69 & 1.0049 & 0.9428 & 90.0 & 99.48 & 60.39 & 0.9957 & 0.8778 \\
\hline 100.0 & 100.00 & 13.98 & 1.0000 & - & 100.0 & 100.00 & 66.97 & 1.0000 & - \\
\hline \multicolumn{10}{|c|}{ Hexane - Butyl methacrylate } \\
\hline \multicolumn{5}{|c|}{$300 \mathrm{~K}$} & \multicolumn{5}{|c|}{$340 \mathrm{~K}$} \\
\hline 0.0 & 0.00 & 0.39 & - & 1.0000 & 0.0 & 0.00 & 3.57 & - & 1.0000 \\
\hline 10.0 & 89.55 & 3.24 & 1.3117 & 0.9941 & 10.0 & 77.59 & 14.10 & 1.1323 & 0.9972 \\
\hline 30.0 & 96.81 & 8.40 & 1.2241 & 1.0116 & 30.0 & 92.89 & 34.72 & 1.1114 & 1.0020 \\
\hline 50.0 & 98.45 & 12.91 & 1.1484 & 1.0564 & 50.0 & 96.68 & 54.15 & 1.0823 & 1.0206 \\
\hline 70.0 & 99.22 & 16.90 & 1.0826 & 1.1571 & 70.0 & 98.43 & 72.13 & 1.0487 & 1.0720 \\
\hline 90.0 & 99.73 & 20.48 & 1.0253 & 1.4719 & 90.0 & 99.51 & 88.80 & 1.0149 & 1.2400 \\
\hline 100.0 & 100.00 & 22.12 & 1.0000 & - & 100.0 & 100.00 & 96.69 & 1.0000 & - \\
\hline \multicolumn{10}{|c|}{ 1,2-Diclorethane - Butyl methacrylate } \\
\hline \multicolumn{5}{|c|}{$300 \mathrm{~K}$} & \multicolumn{5}{|c|}{$340 \mathrm{~K}$} \\
\hline 0.0 & 0.00 & 0.39 & - & 1.0000 & 0.0 & 0.00 & 3.57 & - & 1.0000 \\
\hline 10.0 & 76.12 & 1.44 & 0.9478 & 0.9977 & 10.0 & 61.87 & 8.34 & 0.8881 & 0.9975 \\
\hline 30.0 & 92.50 & 3.57 & 0.9480 & 0.9967 & 30.0 & 86.75 & 18.49 & 0.9199 & 0.9884 \\
\hline 50.0 & 96.75 & 5.80 & 0.9678 & 0.9820 & 50.0 & 94.15 & 29.29 & 0.9492 & 0.9675 \\
\hline 70.0 & 98.66 & 8.15 & 0.9913 & 0.9464 & 70.0 & 97.57 & 40.61 & 0.9742 & 0.9296 \\
\hline 90.0 & 99.67 & 10.49 & 1.0031 & 0.9056 & 90.0 & 99.42 & 52.25 & 0.9933 & 0.8541 \\
\hline 100.0 & 100.00 & 11.58 & 1.0000 & - & 100.0 & 100.00 & 58.18 & 1.0000 & - \\
\hline
\end{tabular}

Using the functional dependences of the saturated vapor pressure we could create the isothermal sections to obtain the dependence of the saturated vapor pressure on solvents concentration. These values were fitted using polynomial, whereby the polynomial order was chosen based on the magnitude of standard deviation between the experimental and the fitted values. The polynomial order was considered acceptable when the standard deviation was comparable to the experimental error.

Further, we calculated the partial vapor pressure of the components using the Duhem-Margules equation [9, $10]$, assuming that the gas phase was close to an ideal gas phase. The equation was solved by the Runge method, integrating in the direction of increased pressure.

The calculation of the partial vapor pressure of each component allowed us to calculate the composition of the gas phase, as well as activity factors of the components $\left(\gamma_{1}\right.$ and $\left.\gamma_{2}\right)$, in the temperature range from 300 to $340 \mathrm{~K}$. Table 2 represents the composition of the liquid phase $(x)$, gas phase $(y)$, as well as the activity factors $\gamma_{1}$ and $\gamma_{2}$, at the minimum and maximum temperature of the experiment.

The resulting values of the equilibrium phases and activity factors allow to calculate the thermodynamic parameters of mixing for the investigated solutions.

To describe the properties of the non-ideal solutions we used the thermodynamic functions of mixing and the excess functions of mixing which were calculated as the difference between the functions of mixing of the experimental and ideal solutions. For instance, the Gibbs energy of mixing and the excess Gibbs energy were calculated based on activity factors of the components: 


$$
\begin{gathered}
\Delta_{m i x} G=R T\left(x_{1} \ln \gamma_{1} x_{1}+x_{2} \ln \gamma_{2} x_{2}\right) \\
G^{E}=R T\left(x_{1} \ln \gamma_{1}+x_{2} \ln \gamma_{2}\right)
\end{gathered}
$$

The excess enthalpy of mixing of our systems is then calculated based on activity factors of the components at different temperatures:

$$
H^{E}=-R T^{2} \cdot\left[x_{1} \cdot\left(\frac{\partial \ln \gamma_{1}}{\partial T}\right)_{x}+x_{2} \cdot\left(\frac{\partial \ln \gamma_{2}}{\partial T}\right)_{x}\right]
$$

The results of these calculations (the concentration dependence of thermodynamic functions mixing) are shown in Figs.1-4.

All systems within the whole range of concentrations and temperatures exhibit negative magnitudes of Gibbs energy of mixing; this indicates the formation of stable solutions, which are non-disposed to segregation.

The systems with benzene and 1,2-diclorethane exhibit negative magnitudes of the excess Gibbs energy of mixing, suggesting the negative deviation from the Raoult's law. Systems with acetonitrile and hexane have positive magnitudes of the excess Gibbs energy of mixing, suggesting the positive deviation from the Raoult's law.

The enthalpy of mixing of butyl methacrylate with 1,2-diclorethane at $300 \mathrm{~K}$ has negative magnitudes within the whole range of concentrations, indicating the formation of strong energy bonds between dissimilar molecules in the solution compared to pure substances. The enthalpy of mixing of butyl methacrylate with benzene at $300 \mathrm{~K}$ has a value close to zero. It indicates the energy equivalency of intermolecular bonds between homogeneous and heterogeneous molecules in this system. Enthalpy of mixing of butyl methacrylate with hexane and acetonitrile has positive values in all investigated concentration range, i.e. the energy value of bonds between heterogeneous molecules is smaller than that of the pure components.

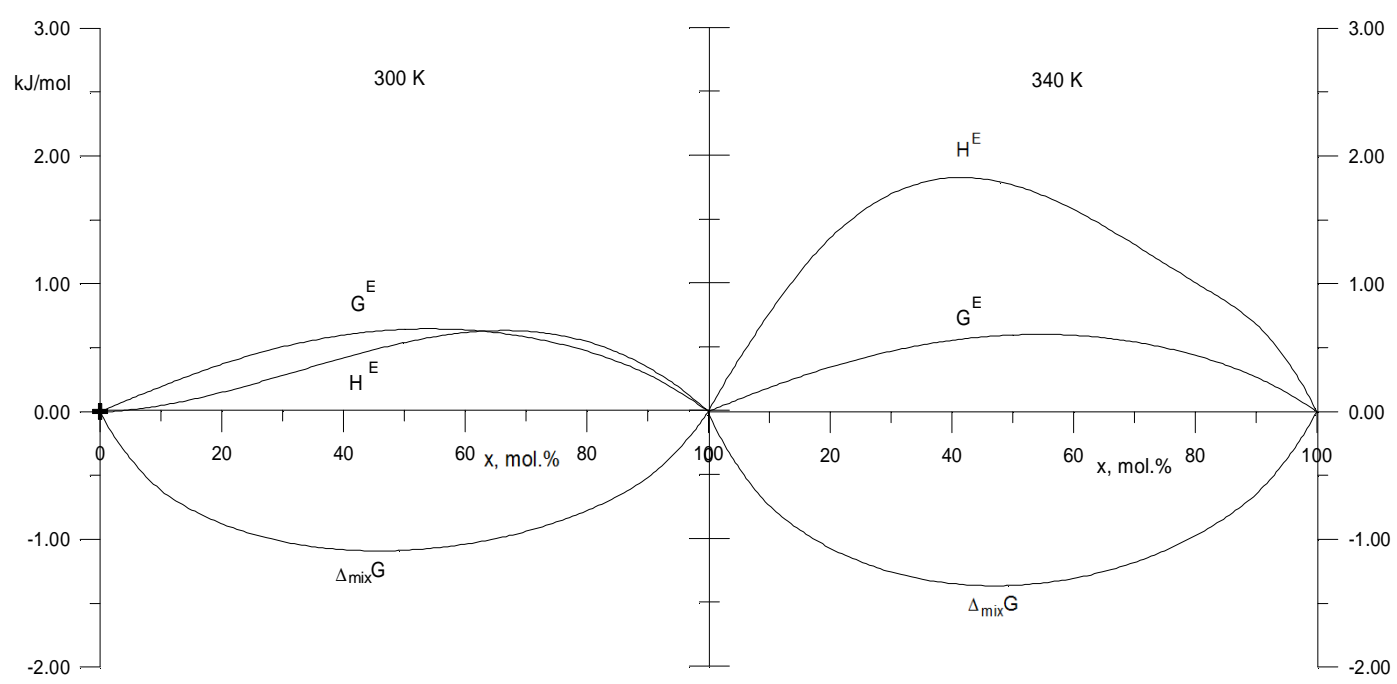

Fig. 1. The thermodynamic functions of mixing for acetonitrile - butyl methacrylate system

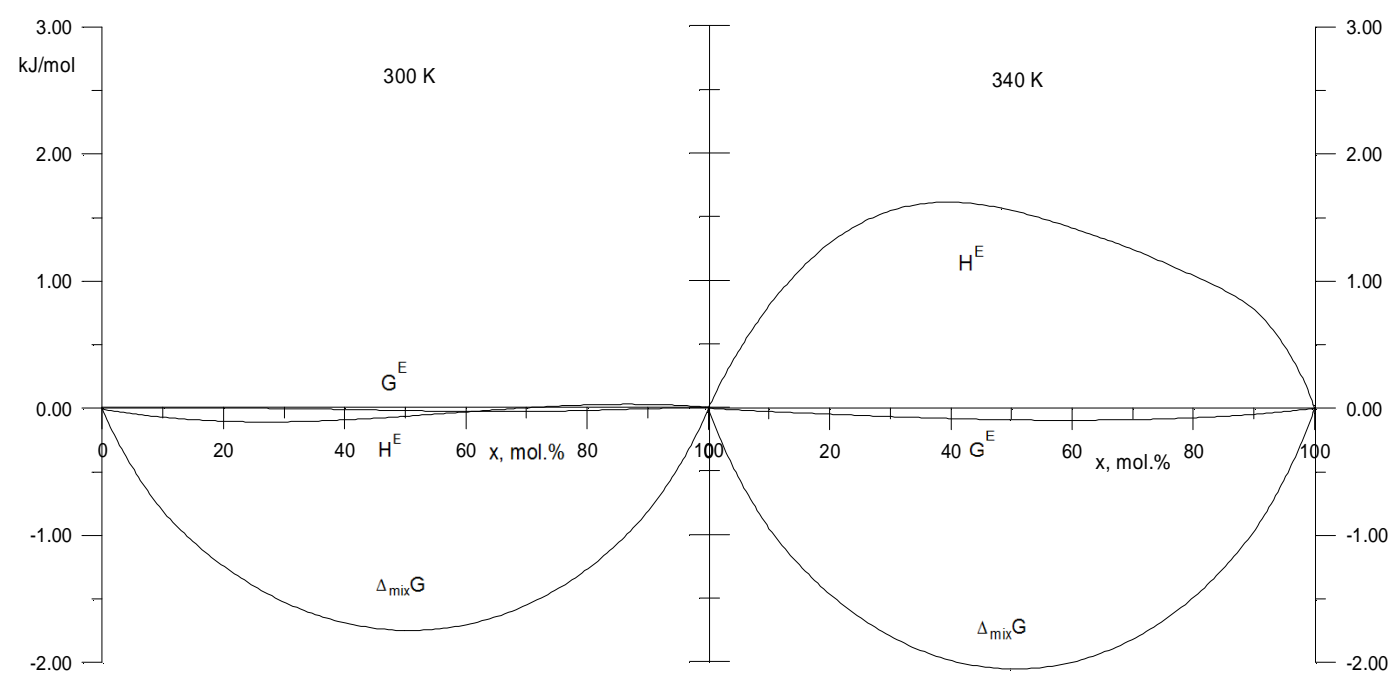

Fig. 2. The thermodynamic functions of mixing for benzene - butyl methacrylate system 


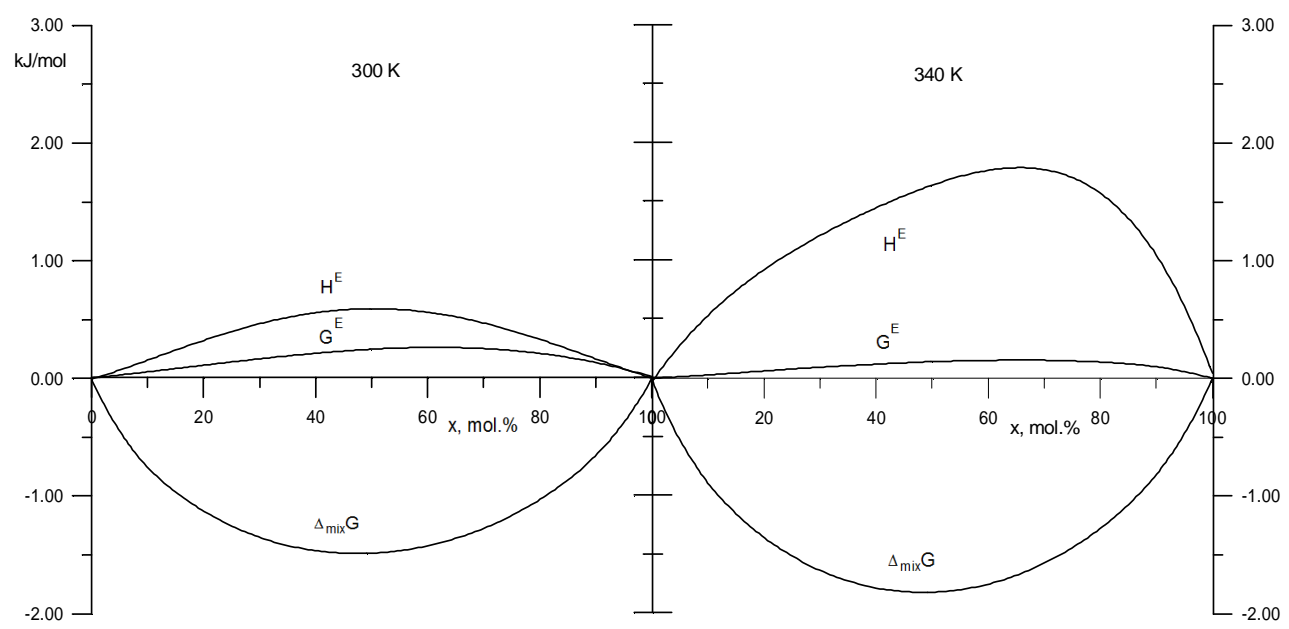

Fig. 3. The thermodynamic functions of mixing for hexane - butyl methacrylate system

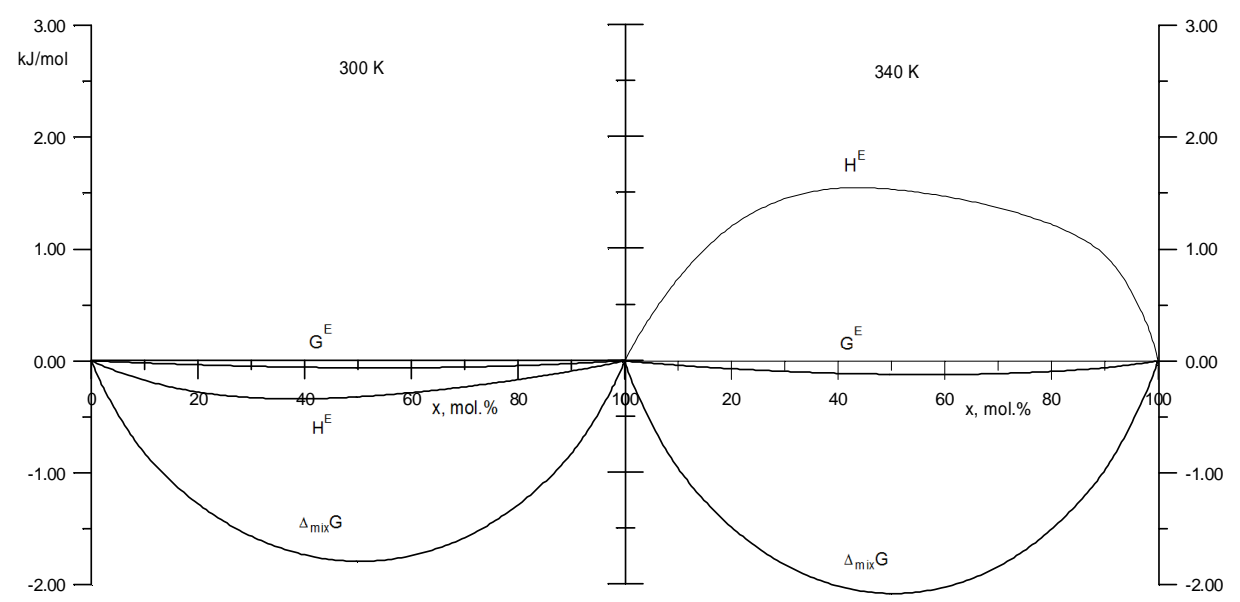

Fig. 4. The thermodynamic functions of mixing for 1,2-diclorethane-butyl methacrylate system

With increasing temperature, the excess enthalpy of mixing increases for all systems and is positive over the entire range of concentrations, indicating a positive magnitude of change of heat capacity while forming the solutions.

With regard to the increase in enthalpy of mixing the investigated solvents can be placed in the following order:

1,2-diclorethane $<$ benzene $<$ acetonitrile $<$ hexane

In this row the dielectric constant of solvents, i.e. their polarity decreases. The exception is acetonitrile, which is a highly polar substance. The obtained values of enthalpy of mixing show that for nonpolar and weakly polar solvents the energy of interaction between the molecules of the solvent and butyl methacrylate is reduced with the decrease in their polarity.

\section{Conclusions}

Determined values of the equilibrium phases can be useful to calculate the processes of the investigated systems separation. The calculated by us activity factors of components can be used to determine the reactivity of these compounds.

Thermodynamic functions of mixing of the investigated systems showed the specificity of interaction between system components and demonstrated deviations of their properties from the properties of ideal solutions. These values demonstrated the energy interaction between dissimilar molecules in the solution and allowed to establish the dependence between thermodynamic parameters and properties of the investigated system components.

\section{References}

[1] Van-Chin-Syan Yu., Kochubei V., Sergeev V. et al.: Zh. Fizich. Khim. A, 1996, 70, 1932.

[2] Eck B., Maurer G.: Fluid Phase Equilibr., 2003, 209, 281. https://doi.org/10.1016/S0378-3812(03)00128-6

[3] Tu C.-H., Wu Y.-S., Liu T.-L.: Fluid Phase Equilibr., 1997, 135, 97. https://doi.org/10.1016/S0378-3812(97)00054-X 
[4] Danov S., Obmelyuhina T., Chubarov G.: Rus. J. Appl. Chem., $1990,63,596$.

[5] Dolgopolov A., Obmelyuhina T., Danov S.: Rus. J. Appl. Chem., 1991, 64, 1994.

[6] Scatchard G., Wilson G.: J. Amer. Chem. Soc., 1964, 86, 133. https://doi.org/10.1021/ja01056a004

[7] Renon H., Prausnitz J.: Ind. Eng. Chem. Proc. Des. Dev., 1968, 7, 220. https://doi.org/10.1021/i260026a011

[8] Sergeev V., Kos Yu., Van-Chin-Syan Yu.: Rus. J. Phys. Chem. A, 2011, 85, 229. https://doi.org/10.1134/S0036024411020300

[9] Serheyev V.: Chem. Chem. Technol., 2015, 9, 15.

[10] Serheyev V., Kos Yu., Van-Chin-Syan Yu.: Chem. Chem. Technol., 2015, 9, 131.

[11] Sergeev V., Van-Chin-Syan Yu.: Rus. J. Phys. Chem. A, 2015, 89, 406. https://doi.org/10.1134/S0036024415030279

[12] Sergeev V.: Rus. J. Phys. Chem. A, 2016, 90, 575.

https://doi.org/10.1134/S0036024416030274

[13] Sergeev V.: Rus. J. Gen. Chem., 2012, 82, 202. https:// doi.org/10.1134/S1070363212020065

[14] Belousov V., Morachevsky A.: Teploty Smesheniya Zydkostei. Khimiya, Leningrad 1970.
[15] Boublik T., Fried V., Hala E.: The Vapour Pressure of Pure Substances. Elsevier, Amsterdam 1973.

Received: February 02, 2017 / Revised: May 31, 2017 / Accepted: September 11, 2017

\section{ТЕРМОДИНАМІЧНІ ВЛАСТИВОСТІ РОЗЧИНІВ БУТИЛМЕТАКРИЛАТУ В ОРГАНІЧНИХ РОЗЧИННИКАХ}

Анотація. Статичним тензиметричним методом було виміряно тиск насиченої пари над розчинами бутилметакрилату в ацетонітрилі, бензені, гексані та 1,2- дихлоретані в температурному інтервалі 293 - 351 К. За даними температурної залежності тиску насиченої пари розраховано склад рівноважних фаз та коефіцієнти активності компонентів. За температурною та концентраційною залежністю коефічієнтів активності розраховані термодинамічні функиії змішування досліджених розчинів.

Ключові слова: бутилметакрилат, тиск насиченої пари, коефіцієнти активності, рівновага рідина-пара, надлишкові термодинамічні функиії. 